\title{
Recenzja książki Magdaleny Grycman, Moniki Jerzyk i Magdaleny Bucyk, Model aktywny. Komunikacja wspomagajqca i alternatywna, Wydawnictwo Poligraf, Wrocław 2020, ss. 454, ISBN 978-83-939907-3-3
}

Szeroko rozumiana komunikacja, a co za tym idzie - możliwość przekazania innym osobom swojej wiedzy, doświadczenia, emocji czy samopoczucia, jest niezwykle ważnym elementem życia każdego człowieka. W momencie gdy się to czyta, brzmi to trywialnie, ale kryje w sobie całe spektrum działań mających na celu umożliwienie komunikacji lub poprawienie jej jakości. Jej tłem są sytuacje rodzinne, szkolne czy społeczne. W przypadku gdy rozważamy ją, myśląc o dzieciach i dorosłych ze złożonymi potrzebami komunikacyjnymi, dostrzegamy konieczność wprowadzenia umożliwiających im porozumiewanie się indywidualnych systemów komunikacyjnych i metod aktywnych w komunikacji. Publikacje dotyczące komunikacji alternatywnej i wspomagającej (augmentative and alternative communication - AAC) są nieliczne. Można je podzielić na te, które opisują określone metody, jak na przykład książka pod redakcją Jacka J. Błeszyńskiego [2006], czy te, które podejmują próbę przedstawienia ujęcia lingwistyczno-logopedycznego, jak pozycje autorstwa Mirosława Michalika [2018; 2020]. Pojawiły się także publikacje o charakterze praktycznym, można nawet powiedzieć metodycznym, jak prace Magdaleny Grycman [2014] i Moniki Jerzyk [2018]. Jednak świat AAC nadal jest obszarem, który wymaga badań i współpracy naukowców ze specjalistami - praktykami. Kolejną książką,

\footnotetext{
* Uniwersytet Kazimierza Wielkiego w Bydgoszczy, Wydział Pedagogiki, Katedra Pedagogiki Specjalnej i Logopedii, ul. Powstańców Wlkp. 2, 85-090 Bydgoszcz, e-mail: a.kamwaw@ukw.edu.pl, ORCID: https://orcid.org/0000-0002-0545-6416.
} 
która pojawiła się na rynku wydawniczym, jest Model aktywny. Komunikacja wspomagajaca i alternatywna, autorstwa Magdaleny Grycman, Moniki Jerzyk i Magdaleny Bucyk.

We wstępie książki czytamy, że jest ona skierowana do praktyków, terapeutów, nauczycieli i rodziców oraz wszystkich zainteresowanych zagadnieniami komunikacji alternatywnej i wspomagającej. Jest efektem wieloletniego doświadczenia zawodowego każdej z autorek. Jako myśl przewodnią można zacytować następujący fragment:

\section{[...] oddziaływania z zakresu komunikacji wspomagającej przynoszą skutek tylko wówczas, gdy zostaną osadzone w naturalnym środowisku osoby niemówiącej (s. 15).}

Tworzy on oś, wokół której autorki budują całą narrację książki. Można to dostrzec już w spisie treści. Publikacja składa się z czterech rozdziałów: Kryteria tworzenia skutecznych oddziaływań z zakresu komunikacji alternatywnej i wspomagajacej (AAC) - środowisko rodzinne; Kryteria tworzenia skutecznych oddzialywań z zakresu komunikacji alternatywnej i wspomagajacej (AAC) - pojęcia kluczowe; Kryteria tworzenia skutecznych oddziaływań z zakresu komunikacji alternatywnej $i$ wspomagajacej (AAC) - indywidualny system komunikacji; Kryteria tworzenia skutecznych oddziaływań z zakresu komunikacji wspomagającej i alternatywnej (AAC) - środowisko szkolne. W każdym z nich powtarza się hasło kryteria tworzenia skutecznych oddziaływań z zakresu komunikacji alternatywnej i wspomagającej (AAC), którego zakres jest następnie dookreślany. Te częste powtórzenia można by zmodyfikować, jednak ich zastosowanie nie obniża wartości merytorycznej omawianej publikacji. Natomiast części tytułów doprecyzowujące obszar działania nie budzą już zastrzeżeń. Struktura książki jest bardzo szczegółowa i przejrzysta. Publikacja - zarówno od strony technicznej, jak i językowej (oprócz powtarzającego się w tytułach sformułowania kryteria oddziaływań...) - przygotowana jest prawidłowo.

Rozdział pierwszy w prowadza czytelników w sytuację rodzinną osób ze złożonymi potrzebami komunikacyjnymi. Opisane jest w nim także przygotowanie opiekuna do komunikacji pozawerbalnej i uznania niezależności córki/syna. Autorki, zwracając uwagę na zróżnicowany poziom wiedzy i doświadczenia czytelników, stopniowo zaznajamiają ich ze światem osób niemówiących. Odbywa się to poprzez wyjaśnienie znaczących terminów (złożone potrzeby komunikacyjne, profil komunikacyjny, niepetnosprawność intelektualna, użytkownik AAC). Na tym etapie brakuje jedynie wyjaśnienia, jak autorki rozumieją indywidualny system komunikacji, do którego odwołują się w treści pierwszego rozdziału. Niezwykle ważne są w tej części: dyskusja nad nadal funkcjonującymi w społeczeństwie stereotypami dotyczącymi AAC oraz podkreślenie autonomii dziecka niemówiącego. Można zauważyć, że dzieci niemówiące, ze złożoną niepełnosprawnością, nie są postrzegane jako osobne jednostki, a raczej widziane $\mathrm{w}$ duecie $\mathrm{z}$ rodzicem, który jest ich adwokatem 
i decydentem. Potwierdzają to badacze, którzy coraz częściej i mocniej podkreślają potrzebę autonomii osób z niepełnosprawnością intelektualną (NI). Jak pisze Beata Cytowska [2019, s. 169]:

\begin{abstract}
[...] samodzielność jako przedpole autonomii jest obszarem funkcjonowania osoby z NI, który do niedawna był pod władzą nadopiekuńczych rodziców, nauczycieli, wychowawców. Jednak od około dwóch dekad obserwuje się zmianę świadomości, nie tylko terapeutów i trenerów pracujących z dorosłymi osobami z NI, ale także ich rodziców, wynikającą z coraz większej społecznej akceptacji tej populacji, dostrzegania jej potencjału, a nie tylko ograniczeń, traktowania jako pełnoprawnych obywateli.
\end{abstract}

Tak więc zwrócenie uwagi na autonomię nie tylko podkreśla podmiotowość dziecka/dorosłego z niepełnosprawnością intelektualną, ale także jego prawo do decydowania o sobie - bez względu na to, jakich trudności rozwojowych doświadcza. Uwzględnienie autonomii w procesie komunikacji jest niezwykle ważne nie tylko z perspektywy możliwości jej realizacji poprzez porozumiewanie się z osobami z otoczenia, ale także z perspektywy rodzica, którego rodzicielstwo zatrzymało się na etapie pełnienia funkcji opiekuńczych wobec dorosłego dziecka.

W rozdziale drugim autorki scharakteryzowały modele aktywne, kompetencje partnera komunikacyjnego, schemat postępowania partnera - strategię komunikacyjną, brak intencji komunikacyjnej, użytkowników zależnych od partnera oraz superwizję. Wyjaśniły również podstawowe terminy związane ze zdiagnozowanymi zaburzeniami u dziecka (na przykład zaburzenia zachowania, echolalia) czy z komunikacją alternatywną (na przykład siedziska dla użytkowników AAC, sprawstwo, przekaz wspomagany, intencja komunikacyjna czy inicjatywa użytkownika). Rozdział uzupełniają liczne fotografie przedstawiające określone etapy procesu komunikacyjnego. W podrozdziale Modele aktywne przedstawiono przypadki dzieci, uwzględniające: diagnozę, pytania dotyczące organizacji modelu aktywnego, przestrzeń i pozycję, pomoce AAC, strategię start-stop na ukulele, przebieg, umiejętności, model aktywny oraz wypowiedź rodzica. Został on uzupełniony o sześć przykładów zajęć z podopiecznymi z zespołem genetycznym FOXG1, mózgowym porażeniem dziecięcym, skrajnym wcześniactwem, zespołem genetycznym Mabry’ego oraz ze spektrum autyzmu i niepełnosprawnością intelektualną. Z kolei w podrozdziale Brak intencji komunikacyjnej. Schematy postępowania partnera komunikacyjnego scharakteryzowano przykłady strategii: stosowania sygnału uprzedzającego na cele, człowiek źródłem zaspokojenia potrzeby, wczesny strat-stop, specjalny czas - strategia krążownik, przejmowania inicjatywy. Opisano także trzy przypadki dzieci, w tym z mózgowym porażeniem dziecięcym i z zespołem Coffina-Siris. Natomiast w podrozdziale Użytkownicy zależni od partnera omówiono strategię oglądania filmu z użyciem włącznika typu Big Switch, zabawy z wieżą i gry na instrumentach, rozpoczęcia oglądania bajki, wyboru ulubionej aktywności, wyboru i czytania uczestniczącego wierszy, 
wyboru: prezentacji dynamicznych i piosenek, zabawy poprzez skanowanie wizualne wspomagane przez partnera. Strategie również zostały zobrazowane przykładami zajęć z dziećmi z zespołem Coffina-Sirs, trisomią chromosomu 21, mózgowym porażeniem dziecięcym, zespołem Angelmana, zespołem Retta, rdzeniowym zanikiem mięśni typu I (SMA1). Pokazanie ścieżki terapeutycznej nadaje temu rozdziałowi charakter metodyczny i pozwala przygotować się rodzicowi lub specjaliście, krok po kroku, do prowadzenia zajęć. Cenne jest to, że autorki zdecydowały się pokazać zarówno pracę z dzieckiem z chorobą rzadką, jak i z częściej występującymi zaburzeniami w rozwoju. Całości dopełnia podrozdział Superwizje, który umożliwia terapeutom prowadzącym zajęcia analizę ich przebiegu, a co za tym idzie - dostrzeżenie efektów swojej pracy, i daje możliwość ponownego spojrzenia na zaistniałe trudności. Pozwala to na podnoszenie ich kompetencji terapeutycznych.

Rozdział trzeci dotyczy kryteriów tworzenia skutecznych oddziaływań z zakresu komunikacji alternatywnej i wspomagającej (AAC) - indywidualnego systemu komunikacyjnego. Zawiera on dziewięć podrozdziałów: Indywidualny system komunikacji - wprowadzenie; Zachowania komunikacyjne. Analiza dostępnych użytkownikowi sposobów porozumiewania się; Kod komunikacyjny. Wyłanianie dominujacego sposobu przekazywania informacji; Przekaz wspomagany, Organizacja przestrzeni i pozycja; Dobór słownictwa i lingwistyczna organizacja systemu; Nawigacja po indywidualnym systemie komunikacyjnym; Ocena efektywności porozumiewania się - skala umiejętności komunikacyjnych z zakresu komunikacji alternatywnej $i$ wspomagającej AAC; Zintegrowane elementy indywidualnych systemów komunikacyjnych - przykłady. Pierwsze cztery podrozdziały zapoznają czytelników z definicją indywidualnego systemu komunikacyjnego, stopniowo przechodząc od identyfikowania oraz rozpoznawania znaczenia zachowań komunikacyjnych, poprzez kod komunikacyjny, a kończąc na przekazie wspomaganym - pokazują tym samym ścieżkę nabywania przez użytkownika AAC umiejętności niezbędnych do komunikowania się z bliskimi i otoczeniem. Kolejny podrozdział Dobór słownictwa i lingwistyczna organizacja systemu jest bogato ilustrowany i zawiera tablice ze słownictwem podstawowym, tematycznym, sekcję znaków zawsze dostępnych oraz tablice dynamiczne. Po ich omówieniu scharakteryzowano tworzenie wypowiedzi. Podrozdział ten ma charakter tutorialu. $Z$ kolei podrozdział Ocena efektywności porozumiewania się - skala umiejętności komunikacyjnych z zakresu komunikacji alternatywnej i wspomagajacej AAC nawiązuje do wcześniejszej publikacji Magdaleny Grycman pt. Sprawdź, jak się porozumiewam. Ocena efektywności porozumiewania się dzieci niemówiących wraz z propozycjami strategii terapeutycznych (pierwsze wydanie ukazało się w 2009 roku), która zawiera skalę oceny efektywności porozumiewania się oraz cele AAC poszczególnych etapów oddziaływań. Najciekawszym elementem tego rozdziału jest część zatytułowana Zintegrowane elementy indywidualnych systemów komunikacyjnych - przykłady. Scharakteryzowano w niej między innymi schemat postępowania partnera $\mathrm{w}$ strategii start-stop, strategie: wyboru $\mathrm{z}$ dwóch poprzez 
wyliczanie, rozmowy o potrzebach, opartej na skanowaniu słuchowo-wzrokowym, czytania uczestniczącego, nauki korzystania z tablicy dynamicznej. Uzupełniają je przykłady etapów realizacji zajęć z ich wykorzystaniem przez dzieci ze zdiagnozowanym mózgowym porażeniem dziecięcym i niepełnosprawnością intelektualną oraz rdzeniowym zanikiem mięśni typu I (SMA1). Tak więc autorki ponownie zdecydowały się pokazać model pracy z dzieckiem z często występującymi trudnościami w rozwoju, a także z chorobami rzadkimi. W tym podrozdziale zastanawia zamieszczenie w przypisach dolnych linków do portalu społecznościowego Facebook, na którym umieszczone są filmy nawiązujące do przedstawianych schematów postępowania. Nasuwa się pytanie o trwałość dostępu do tych zasobów w następnych latach, gdy książka będzie bazą do pracy dla kolejnych młodych terapeutów. Jednak pomysł na łączenie treści z filmem jest bardzo cenny w przypadku tego typu publikacji.

Ostatni rozdział zawiera następujące podrozdziały: Interdyscyplinarność oddziaływań; Identyfikowanie obszarów oddziaływań; Osadzenie oddziaływań wspomagajacych $w$ strategiach dotyczacych planowania; Indywidualne systemy komunikacyjne tworzone w warunkach szkolnych - perspektywa rozwojowa; Zajęcia grupowe - wdrażanie działań terapeutycznych o charakterze komunikacyjnym; Przykłady dokumentowania oddzialywań wspierających rozwój kompetencji komunikacyjnych w warunkach szkolnych oraz Aktywne modele w placówkach edukacyjnych - proces wdrażania. Jest to jeden $\mathrm{z}$ najobszerniejszych rozdziałów. Zawiera on wiele krótkich scenariuszy zajęć, związanych między innymi z realizacją strategii korzystania $\mathrm{z}$ toalety, układania planu dnia i zajęć, przygotowywania kanapki, robienia zakupów. Jak można zauważyć, wszystkie wspomniane strategie nawiązują do ćwiczenia umiejętności samoobsługi, poczucia sprawstwa i budowania własnej autonomii. Następnie autorki pokazują możliwości tworzenia indywidualnego systemu komunikacyjnego w warunkach szkolnych. Obrazują to między innymi przykładami z Zespołu Szkół Specjalnych im. I. Komorowskiej w Oławie, Zespołu Placówek Specjalnych w Nysie, Terapeutycznego Punktu Przedszkolnego „Niebieski Latawiec” we Wrocławiu oraz Społecznej Szkoły Podstawowej „Zakątek” w Poznaniu. W ten sposób przedstawiają czytelnikom zróżnicowane środowisko edukacyjno-terapeutyczne dziecka $\mathrm{z}$ trudnościami w rozwoju oraz jego możliwości - zarówno zasoby osobowe, w postaci chętnie podnoszących swoje kwalifikacje terapeutów, jak i materialne, odnoszące się do pomocy i przestrzeni zajęć. Cenne jest pokazanie w tej części przebiegu zajęć z osobą dorosłą - panią Aleksandrą (lat 20, niepełnosprawność sprzężona: intelektualna i ruchowa). Poziom zaproponowanych dla niej aktywności uwzględnia jej wiek. Dlaczego terapeuci i rodzice zwracają na to uwagę? Ponieważ w codzienności terapeutycznej często można dostrzec problem infantylizowania osób dorosłych z niepełnosprawnością intelektualną, nie tylko poprzez zdrobnienia imion i mówienie per „ty”, ubieranie w rzeczy nieadekwatne do wieku, ale także poprzez dobór aktywności, często kojarzonych z dziećmi w młodszym wieku szkolnym, a nawet przedszkolnym. Potwierdza to raport z badań pt. Obiektywna i subiektywna jakość zycia 
dorosłych osób z niepetnosprawnościa intelektualna zamieszkujących województwo wielkopolskie. Uwarunkowania środowiskowe oraz poziom wsparcia realizatorów polityki społecznej przeprowadzony przez Stowarzyszenie Na Tak, w którym czytamy:

Najwięcej respondentów [dorosłych z niepełnosprawnością intelektualną - przyp. A.K.-W.] posiadało własne drobiazgi, takie jak maskotki, zabawki, pamiątki z wydarzeń, w których brali udział. $Z$ doświadczeń badaczy wynika, że takie przedmioty stanowią najczęstszą formę prezentów darowanych osobom z niepełnosprawnością intelektualną. Większość z tych rzeczy ma charakter infantylny, nieprzystający do wieku, co może być związane ze społecznym obrazem dorosłych osób z niepełnosprawnością intelektualną, postrzeganych i traktowanych przez otoczenie jak dzieci. Niejednokrotnie w placówkach dla dorosłych osób z niepełnosprawnością intelektualną spotykano osoby dorosłe bawiące się misiami, maskotkami, zabawkami dla dzieci, balonami [Stowarzyszenie Na Tak, 2016, s. 69].

Tak więc w publikacjach dotyczących funkcjonowania osób niemówiących, z niepełnosprawnością intelektualną istotne jest podkreślanie nie tylko ich autonomii, ale także dorosłości, co można dostrzec w omawianej książce.

Całość uzupełniają zakończenie oraz bibliografia.

Wartością dodaną książki, nadającą podmiotowy wymiar prowadzonej w niej narracji, jest obrazowanie podrozdziałów wypowiedziami rodziców osób ze złożonymi potrzebami komunikacyjnymi, co pozwala dostrzec dylematy opiekunów, ich uczucia związane z wdrażaniem dziecka do indywidualnego systemu komunikacji, a co za tym idzie - do autonomii i samostanowienia. Publikacja jest skierowana między innymi do terapeutów już pracujących z dziećmi ze złożonymi potrzebami komunikacyjnymi. Zdobywającym dopiero doświadczenie specjalistom zapewne zabrakłoby w niej krótkiego wprowadzenia teoretycznego, uwzględniającego między innymi różne koncepcje złożonych potrzeb komunikacyjnych, niemówienia - niemowności czy krótkiego opisu rzadkich zespołów genetycznych (np. zespołu Coffina-Siris), których autorki podają przykłady.

Literatura

Błeszyński J.J., 2006, Alternatywne i wspomagające metody komunikacji, Kraków: Oficyna Wydawnicza „Impuls”.

Cytowska B., 2019, Dorosłość z perspektywy osób z głębszą niepełnosprawnościa intelektualna $w$ świetle zrealizowanych wywiadów pogłębionych, „Niepełnosprawność. Dyskursy Pedagogiki Specjalnej”, nr 34, s. 159-175.

Grycman M., 2014, Porozumiewanie się dzieci ze złożonymi zaburzeniami komunikacji. Podręcznik nie tylko dla rodziców, Kwidzyn: Stowarzyszenie Rehabilitacyjne Centrum Rozwoju Porozumiewania się. 
Jerzyk M., 2018, Oddziaływania wspierające rozwój komunikacji osób z głęboką wielorakq niepetnosprawnością, „Terapia Specjalna”, nr 4, s. 20-23.

Michalik M., 2018, Lingwistyczno-logopedyczne podstawy komunikacji alternatywnej i wspomagającej. Ujęcie metodologiczne, Kraków: Wydawnictwo Naukowe Uniwersytetu Pedagogicznego w Krakowie.

Michalik M., 2020, Linguistics of Augmentative and Alternative Communication in the Process of Diagnosis of Speech Inability and Speech Non-Occurrence, „Logopaedica Lodziensia”, nr 4, s. 131-139.

Stowarzyszenie Na Tak, 2016, Obiektywna i subiektywna jakość życia dorosłych osób $z$ niepetnosprawnościq intelektualna zamieszkujących województwo wielkopolskie. Uwarunkowania środowiskowe oraz poziom wsparcia realizatorów polityki społecznej, Poznań: Obserwatorium Integracji Społecznej działające przy Regionalnym Ośrodku Polityki Społecznej.

\section{cc) creative}

(c) by the author, licensee Łódź University - Łódź University Press, Łódź, Poland. This article is an open access article distributed under the terms and conditions of the Creative Commons Attribution license CC-BY-NC-ND 4.0

(https://creativecommons.org/licenses/by-nc-nd/4.0/)

Data złożenia: 26.02.2021. Data przyjęcia: 23.03.2021. 